\title{
Large Floods in the United States: Where They Happen and Why
}

U.S. Geological Survey Circular 1245

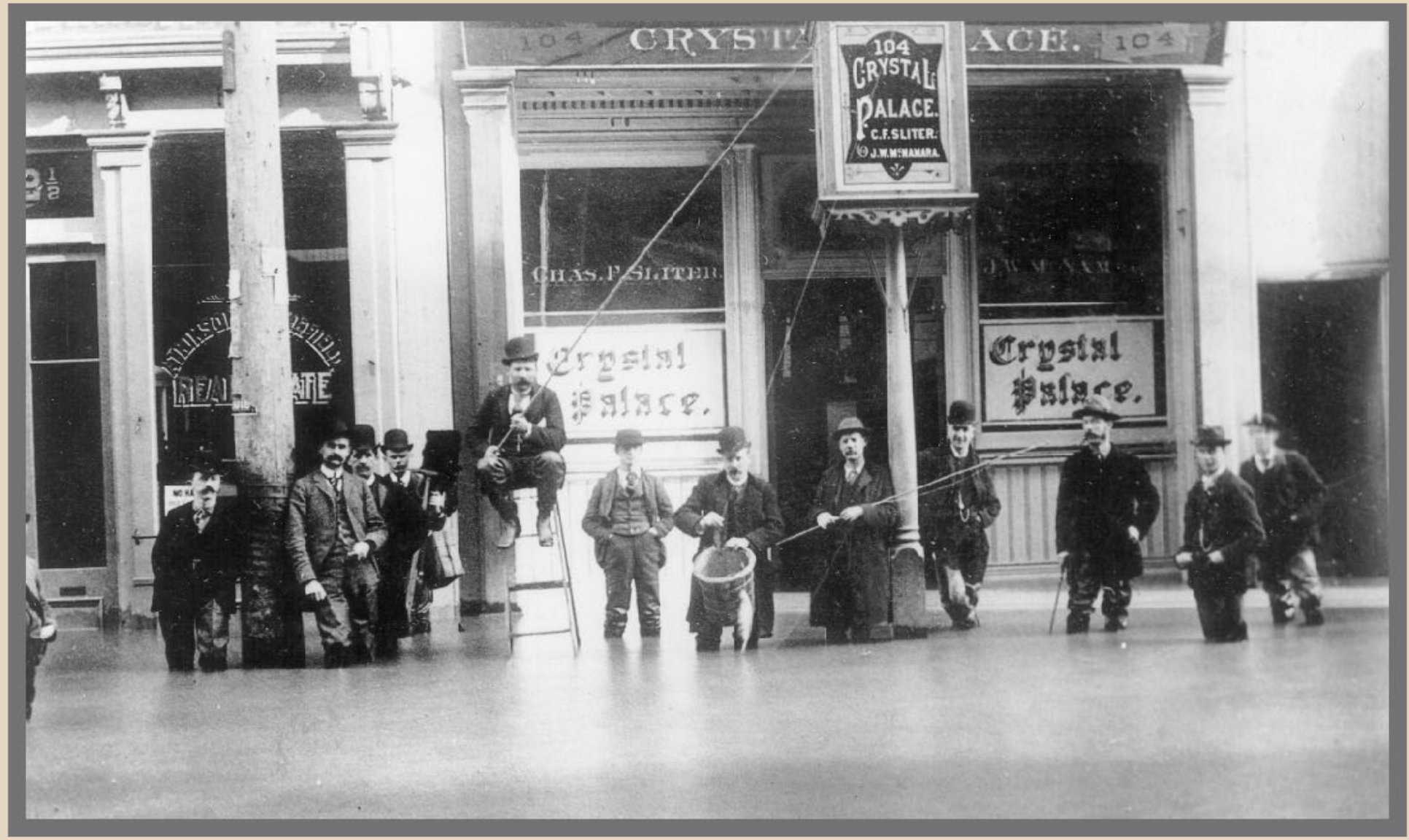

U.S. Department of the Interior

U.S. Geological Survey 


\section{COVER PHOTOGRAPH:}

Rapid late-spring melting of a deep snowpack in June 1894 resulted in the largest flood on record for the Columbia River, which backed up the Willamette River into downtown Portland, Oregon. (Photograph courtesy of Oregon Historical Society; negative number ORH; 9906.) 


\section{Large Floods in the United States: Where They Happen and Why}

By JIM E. O'CONNOR and JOHN E. COSTA 


\section{U.S. DEPARTMENT OF THE INTERIOR}

GALE A. NORTON, Secretary

U.S. GEOLOGICAL SURVEY

CHARLES G. GROAT, Director

The use of trade, product, or firm names in this publication is for descriptive purposes only and does not imply endorsement by the U.S. Government.

2003

\section{Library of Congress Cataloging-in-Publication Data}

O'Connor, Jim E., 1959-

Large floods in the United States : where they happen and why / Jim E., O'Connor and John E. Costa.

p. cm. -- (U.S. Geological Survey circular ; 1245)

Includes bibliographical references.

ISBN 0-607-89380-X (pbk.)

1. Floods--United States. 2. Flood forecasting--United States. I. Costa, John E. II.

Geological Survey (U.S.) III. Title. IV. Series.

GB 1399.3.033 2003

$551.48^{\prime} 9^{\prime} 0973--d c 21$

2003043891 


\section{CONTENTS}

Floods_-A National Hazard .............................................................................................. 1

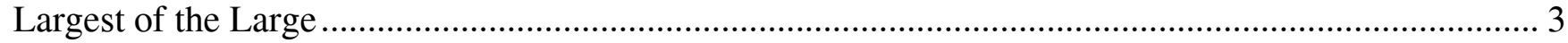

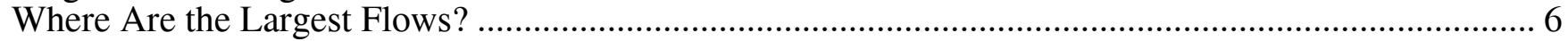

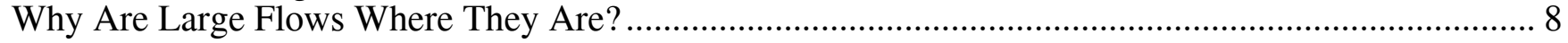

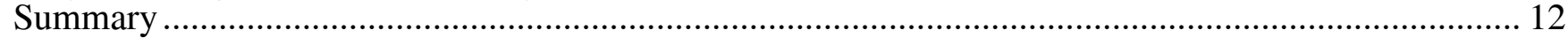

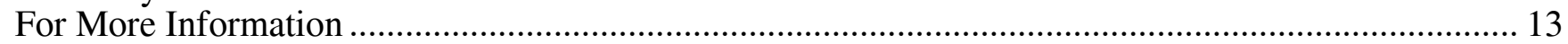

FIGURES

1. The U.S. Geological Survey has collected streamflow measurements at more than 23,000 gaging stations on streams and rivers throughout the United States and Puerto Rico....................... 2

2. The streamflow gage on the Willamette River near Salem, Oregon, is one of many in the Willamette Valley and is typical of the more than 7,000 active USGS gages on streams and rivers in the U.S. and Puerto Rico.

3. The largest annual flow from each of 22,063 streamflow stations in the U.S. and Puerto Rico.......... 5

4. Locations of 2,929 stations, color coded by drainage area, for which the largest peak discharge

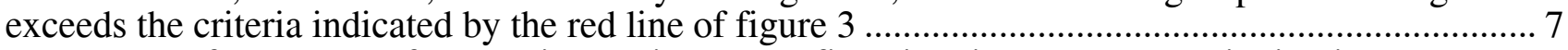

5. The subset of large-stormflow gaging stations, as defined in this report, has a distribution similar to that of all U.S. Geological Survey gaging stations relative to the size of the basin being gaged 2

6. Rainfall amounts are relatively smaller in storms that have a greater than 6-hour duration

and that exceed about 1,000 square miles in area..... 


\title{
Large Floods in the United States: Where They Happen and Why
}

\author{
By Jim E. O'Connor and John E. Costa
}

\section{FLOODS-A NATIONAL HAZARD}

Floods are the most chronic and costly natural hazard in the United States, causing an average of 140 fatalities and $\$ 5$ billion damage each year (Schildgen, 1999). Despite advances in flood science and implementation of Federal hazard-reduction policies, damage from flooding continues to escalate (Pielke and Downton, 2000). Damage from floods results from a combination of the great power of flowing water and the concentration of people and property along rivers. In the United States, about 3,800 towns and cities of more than 2,500 inhabitants are on floodplains (Miller and Miller, 2000).

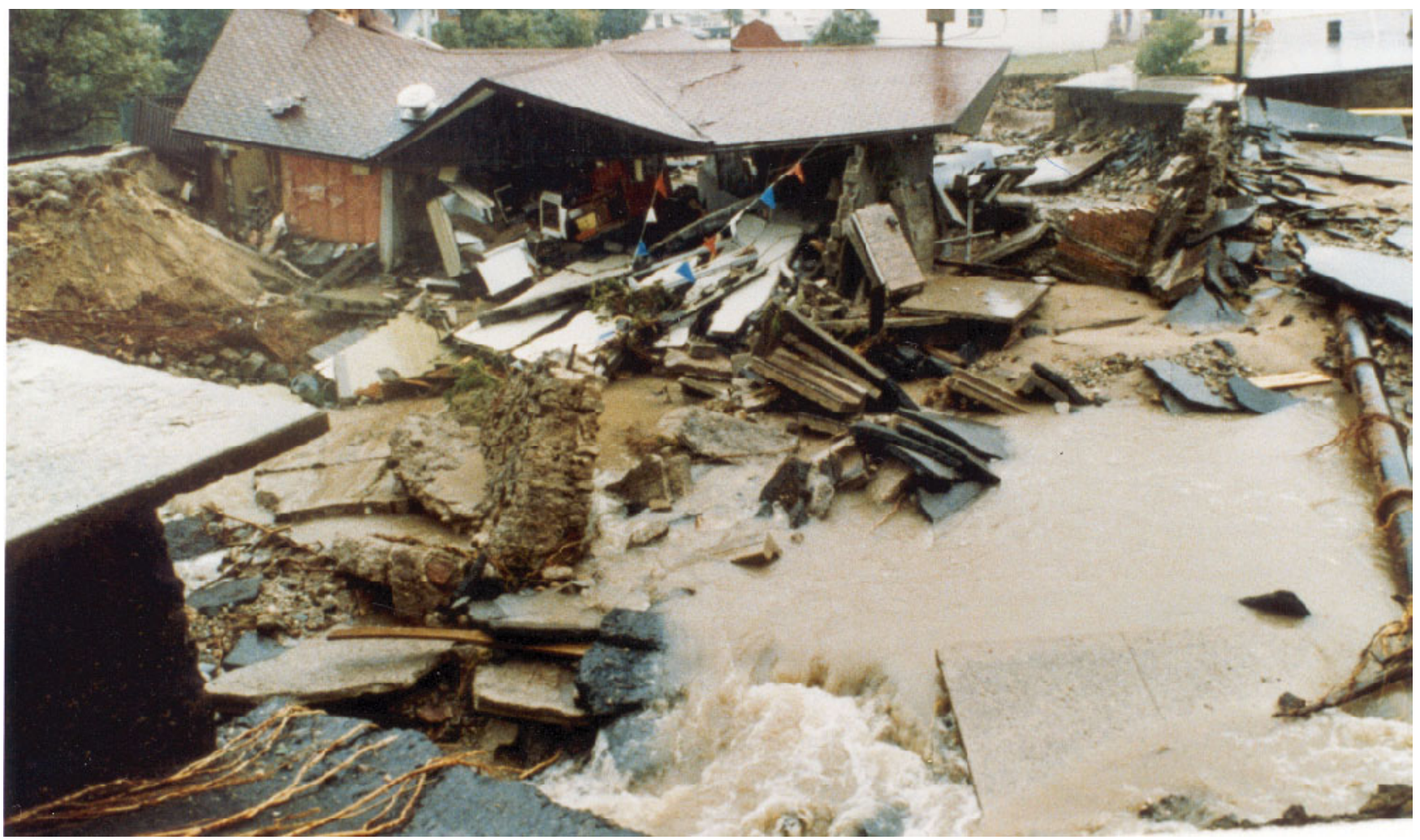

Persistent, widespread torrential rainfall caused flooding across central Michigan in September 1986, resulting in unprecedented damage. (Photograph by Scott Harmesen, Bay City Times, used by permission.) 


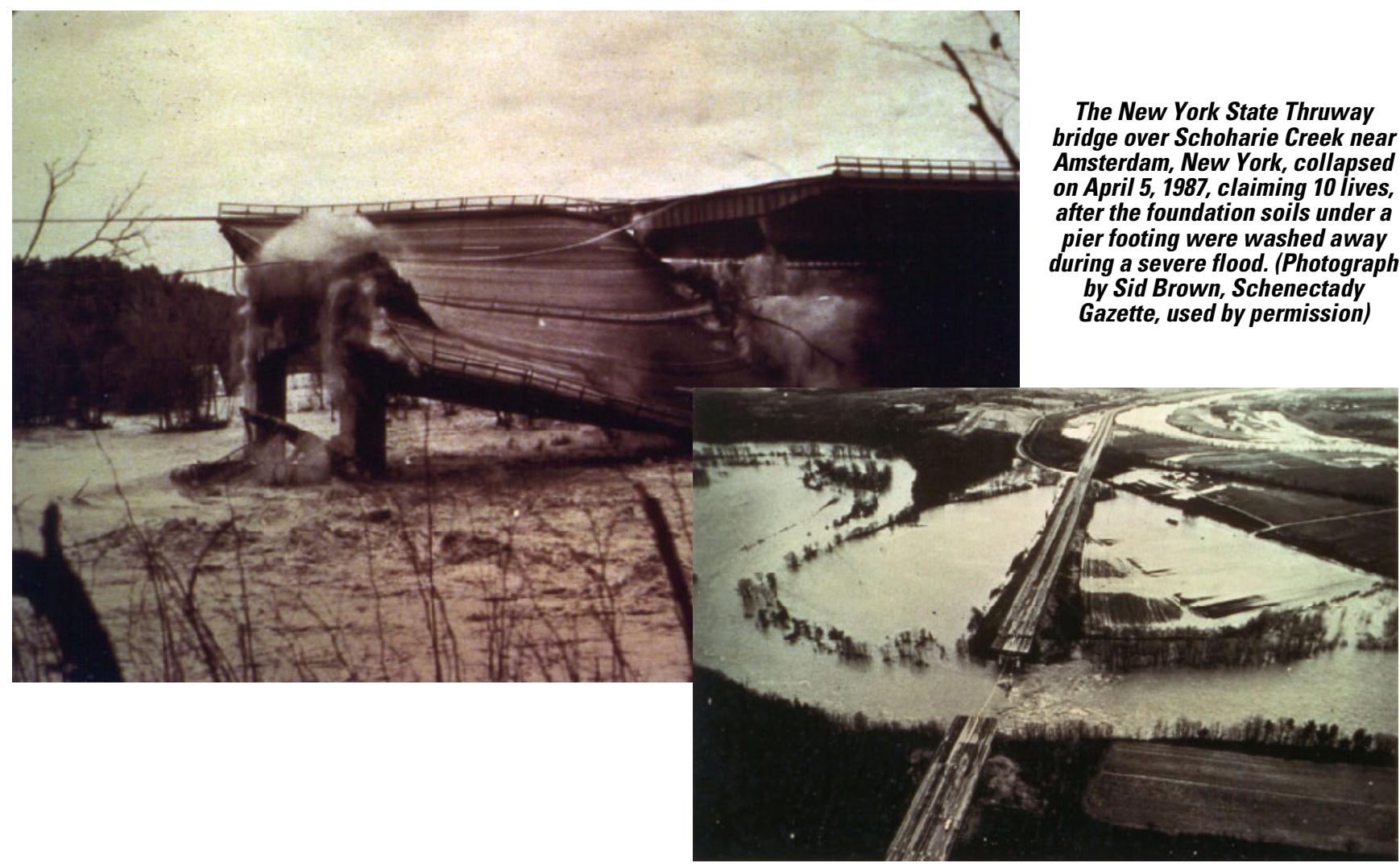

Damaging floods result when the volume of river flow exceeds levels of flood preparedness, either because flow is greater or longer than expected or because of incomplete understanding of local hazards. Consequently, a primary means of reducing flood hazards is by better understanding the magnitude and likelihood of large flows. The data underlying most studies of flood magnitude and frequency in the United States are records of U.S. Geological Survey (USGS) streamflow gages (fig. 1), which for the last 110 years have been collecting streamflow data at more than 23,000 locations (although not all the streamflow-gaging stations have operated continuously). This circular summarizes the locations and magnitudes of large flows recorded by these gaging stations, showing locations in the United States where relatively large floods occur, and describes, in general terms, some of the climatologic and topographic factors that contribute to large floods.

The source of data for this analysis of large U.S. floods is the peak flow files maintained as part of the USGS National Water Information System. These files are maintained for each streamflow-gaging station and include values for the largest instantaneous discharge (peak flow) for each water year (October 1 to September 30) (see for example, fig. 2). As of June 2002, there were records for 23,216 stations on streams of all sizes that together comprise more than a million annual peak flow measurements and estimates. These measurements do not account for or signify the damage caused by floods, but simply indicate the maximum volume of water passing the gaging station during the peak of the flood.

\section{LARGEST OF THE LARGE}

From these peak flow files, we extracted the single largest flood discharge (excluding damfailure floods) from all stations that monitor flow from drainage areas greater than $0.01 \mathrm{mi}^{2}$ (square miles) $\left(0.26 \mathrm{~km}^{2}\right.$ [square kilometers]). This resulted in records of the maximum flood from 


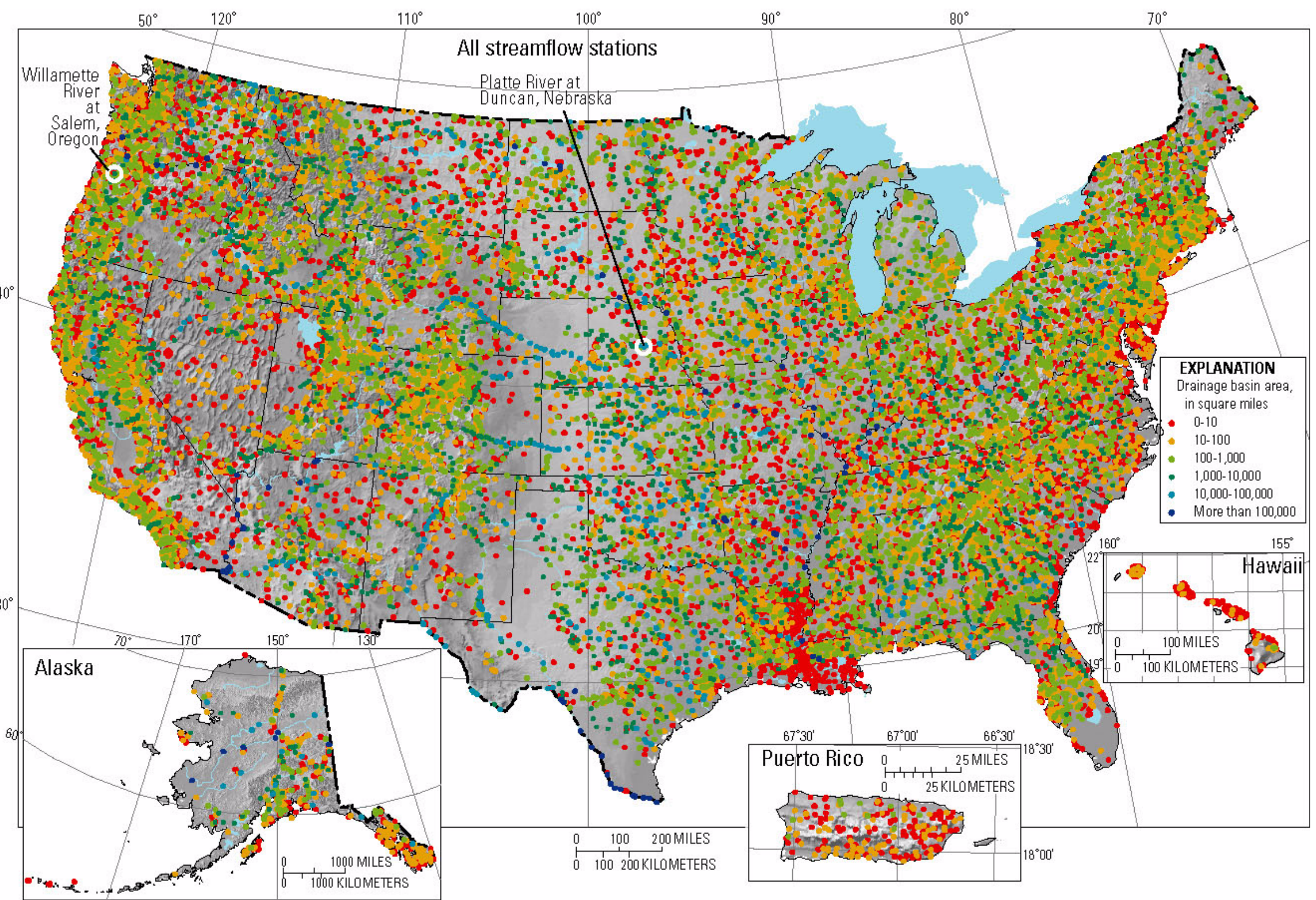

Figure 1. The U.S. Geological Survey has collected streamflow measurements at more than 23,000 gaging stations on streams and rivers throughout the United States and Puerto Rico. Some stations have recorded flow since the late 1800 s. About 7,000 stations are presently active. This map shows all 22,063 stations, color coded by drainage area, for which there are records of the largest flow for each year that the gage was operated. Typical long-term stations are the Willamette River at Salem, Oregon, which has recorded flow daily since 1909 (and has information for historic peak discharges back to 1861), and the Platte River near Duncan, Nebraska, which has collected daily flow measurements since 1928 and has peak discharges back to 1896. 


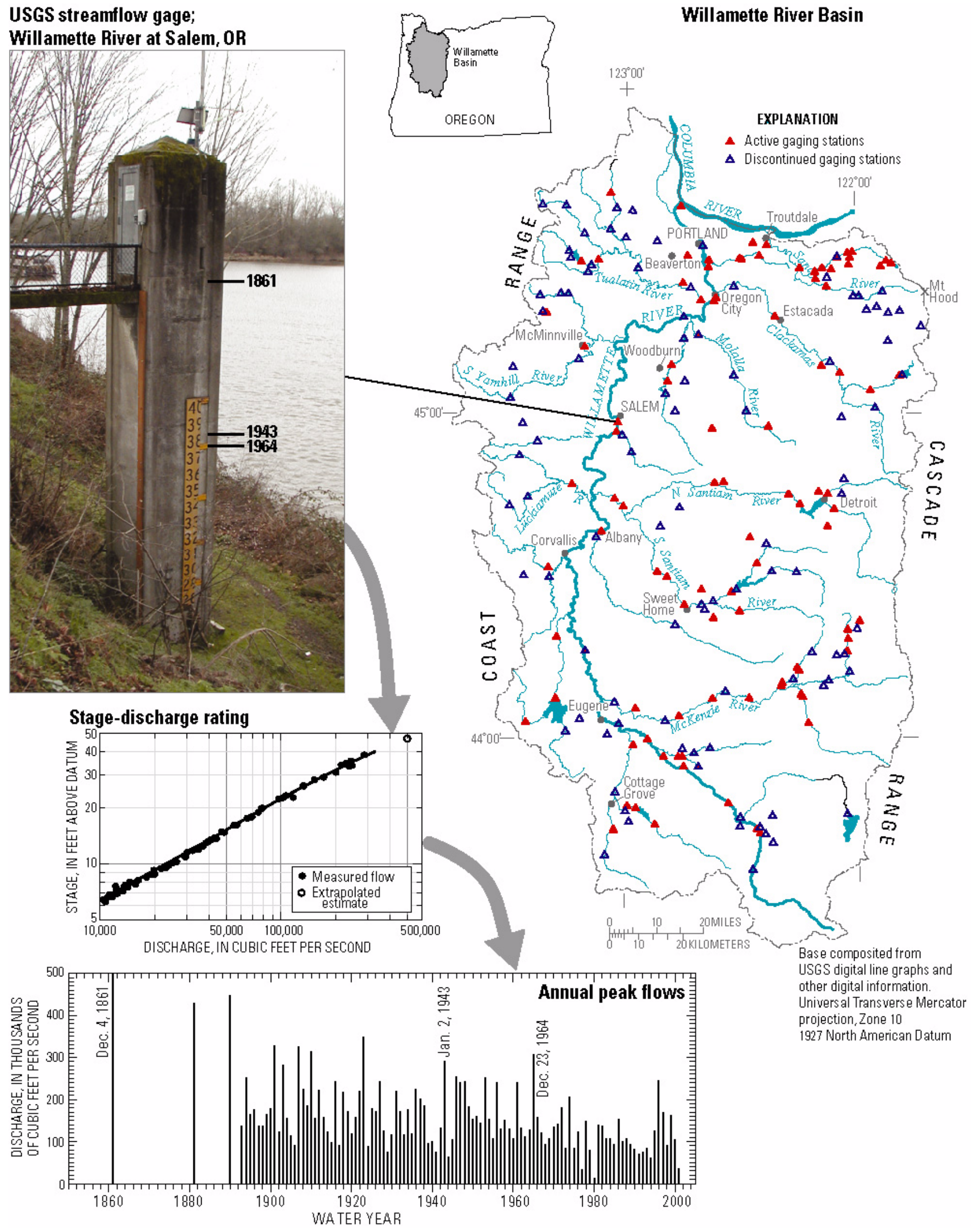


Figure 2. The streamflow gage on the Willamette River near Salem, Oregon, is one of many in the Willamette Valley and is typical of the more than 7,000 active USGS gages on streams and rivers in the U.S. and Puerto Rico. Most stations monitor river stage (elevation of the water surface), which is then converted to discharge (flow volume per unit time) by use of a stage-discharge rating curve. These rating curves are derived from and continuously updated by several measurements per year of flow discharge and stage (indicated by the solid dots). The largest flow of each water year (October through September), either directly measured or, more commonly, determined from the highest recorded stage and the rating curve, is compiled into the station's peak flow file. The annual peak flows for this station are shown on the bottom plot, including notable floods in 1861, 1943, and 1964. The generally smaller magnitude of peak flows since the 1960s owes to construction of several flood control reservoirs in the basin.

each of 22,063 stations (fig. 1). Discharge values ranged from $1 \mathrm{ft}^{3} / \mathrm{s}$ (cubic feet per second) $\left(0.03 \mathrm{~m}^{3} / \mathrm{s}\right.$ [cubic meters per second]) to 2.47 million $\mathrm{ft}^{3} / \mathrm{s}\left(70,000 \mathrm{~m}^{3} / \mathrm{s}\right)$ with drainage areas up to 1.13 million $\mathrm{mi}^{2}$ (2.93 million $\mathrm{km}^{2}$ ) (fig. 3). These records include discharge estimates for historic floods at gaging stations dating back to the late $18^{\text {th }}$ century as well as all gaged measurements through water year 1997 (September 30, 1997). The majority of these floods were caused by weather and climate conditions, such as rainfall and snowmelt, but many were also affected by regulation and diversion. Most of these flows were not directly measured at the time, but were estimated from post-flood surveys and calculations or by comparing elevations of maximum flood levels to past measured flows (fig 2).

In general, larger flows have come from larger drainage basins because they accumulate more rain and snow (fig. 3). Despite this overall

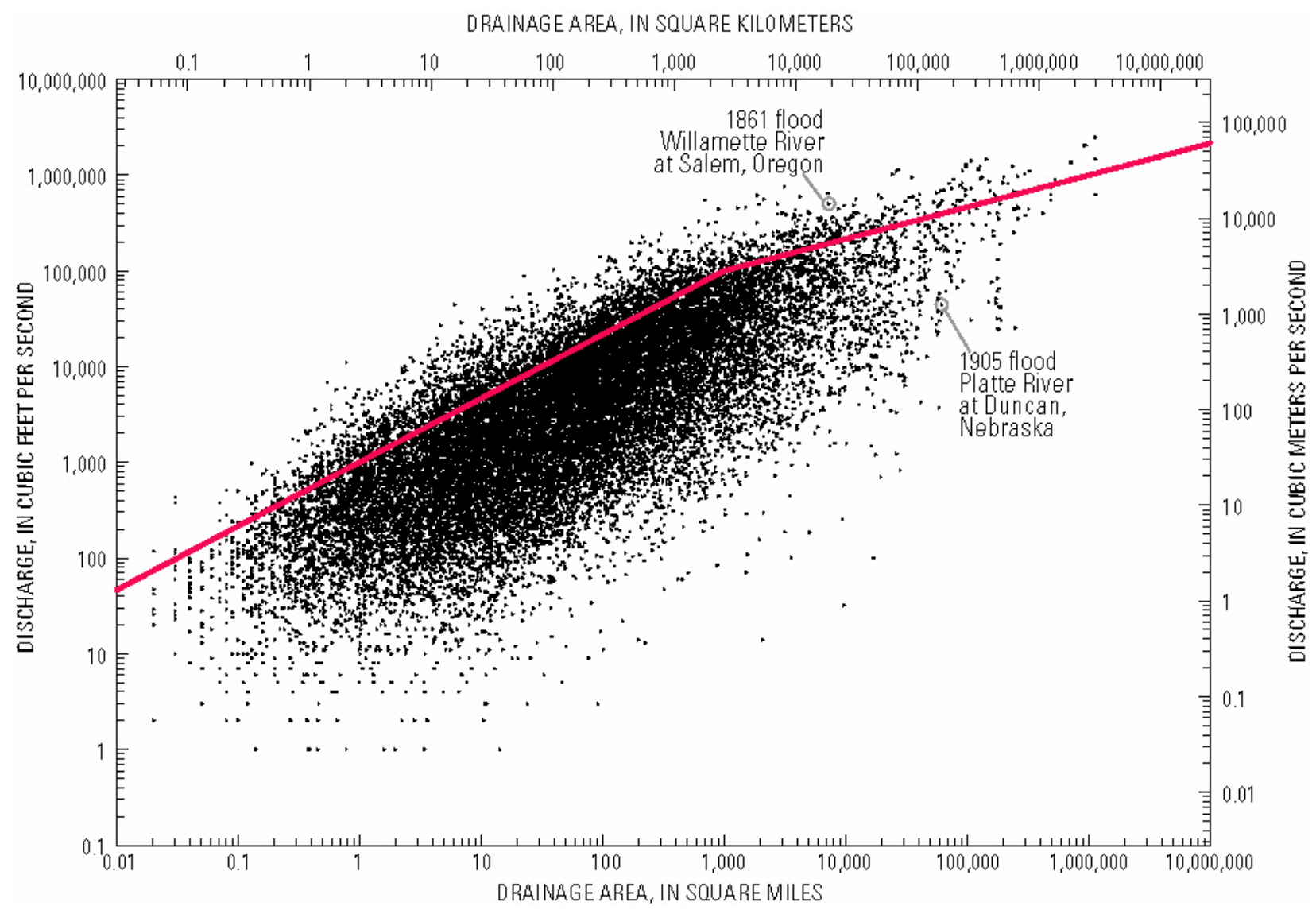

Figure 3. The largest annual flow from each of 22,063 streamflow stations in the U.S. and Puerto Rico. In general, larger basins produce larger-peak flows, although there is substantial variation. Points above the red line, such as the 500,000 cubic feet per second peak discharge on the Willamette River at Salem, are the largest 13 percent of these flows, relative to drainage area. The stations recording these largest flows are shown on figure 4. 
relation between basin size and peak flow, some basins produce larger flows than other, similarly sized or even larger basins. To identify the basins that produce the largest floods relative to drainage area, we determined which stations had flows that exceeded the criteria:

$$
\begin{gathered}
\mathrm{Q}>1,000 A^{0.667} \text { for } \mathrm{A}<1,000 \text { and } \\
\mathrm{Q}>10,000 \mathrm{~A}^{0.333} \text { for } \mathrm{A} \geq 1,000,
\end{gathered}
$$

where $\mathrm{Q}$ is the peak discharge in cubic feet per second and $\mathrm{A}$ is the drainage area in square miles. This set of equations is represented by the red line in figure 3. The largest flood for each streamflow gaging station meets or exceeds the criteria for 2,929 stations, about 13 percent of the 22,063 stations with peak flow records. For example, the largest flood for the streamflow-gaging station "Willamette River at Salem," for which 500,000 $\mathrm{ft}^{3} / \mathrm{s}$ was estimated for December 9, 1861, plots well above the line, considering the 7,280 $\mathrm{mi}^{2}$ drainage area of the station. In contrast, the largest flow in nearly 100 years of record for the "Platte River at Duncan," which records flow from a much larger basin of $60,900 \mathrm{mi}^{2}$, was the 44,000 $\mathrm{ft}^{3} / \mathrm{s}$ flood of June 23, 1905, a value that plots well below the line. The locations of stations with the largest relative flows - those that fall above the line-are shown on figure 4, which forms the basis of our conclusions on some of the geographic and meteorologic controls on large flows within the United States.

The two criteria for stations with contributing basins smaller and larger than $1,000 \mathrm{mi}^{2}(2,690$ $\mathrm{km}^{2}$ ) result in the slope change of the red line shown in figure 3 . In developing these criteria for defining the large-flow stations, we found that this slope change was necessary to ensure that our subset of large-flow stations was not biased relative drainage area. In other words, the statistical distribution of drainage areas for stations plotting above the line is similar to the distribution of areas contributing to all of the analyzed stations (fig. 5).
Beyond providing an unbiased selection of large-flow stations, the change in slope of the large-flow criteria for drainage basins larger that $1,000 \mathrm{mi}^{2}\left(2,560 \mathrm{~km}^{2}\right)$ likely reflects physical processes underlying flood runoff. For example, similar slope decreases appear in envelope curves bounding the maximum global and U.S. rainfall-runoff floods (Costa, 1987) as well as some exceptional regional floods resulting from individual storms (Miller, 1990). Further, the decrease in slope for the large-flow criterion separating the largest U.S. gaged flows corresponds with the marked drop-off in rainfall depth for U.S. storms with areas larger than $1,000 \mathrm{mi}^{2}\left(2,690 \mathrm{~km}^{2}\right)$ and durations greater than 6 hours (fig. 6), and may reflect limits on storm size and rainfall rates, perhaps corresponding to the spatial extent of intense convective precipitation within tropical storms.

\section{WHERE ARE THE LARGEST FLOWS?}

The geographic distribution of stations with the largest flow magnitudes relative to drainage area (fig. 4) is substantially different from the distribution of all stations (fig. 1), showing that the distribution of large flows is not random but must reflect climate and landscape properties. It is also evident, however, that the distribution of stations with large floods depicted in figure 4 is locally biased by areas of high concentrations of flow stations, such as in the Dallas-Fort Worth and Houston metropolitan areas in Texas, and in the Appalachians of Virginia and Maryland. Nevertheless, there are notable concentrations of exceptional flows, such as in Hawaii and Puerto Rico, where 78 percent of the 441 stations have maximum station discharges above the large-flow criteria shown in figure 3.

Within the conterminous United States, certain areas produce larger flows than others. Particularly notable are the concentrations of relatively large flows in central Texas and in the central and northern Appalachians. Also evident are relatively 


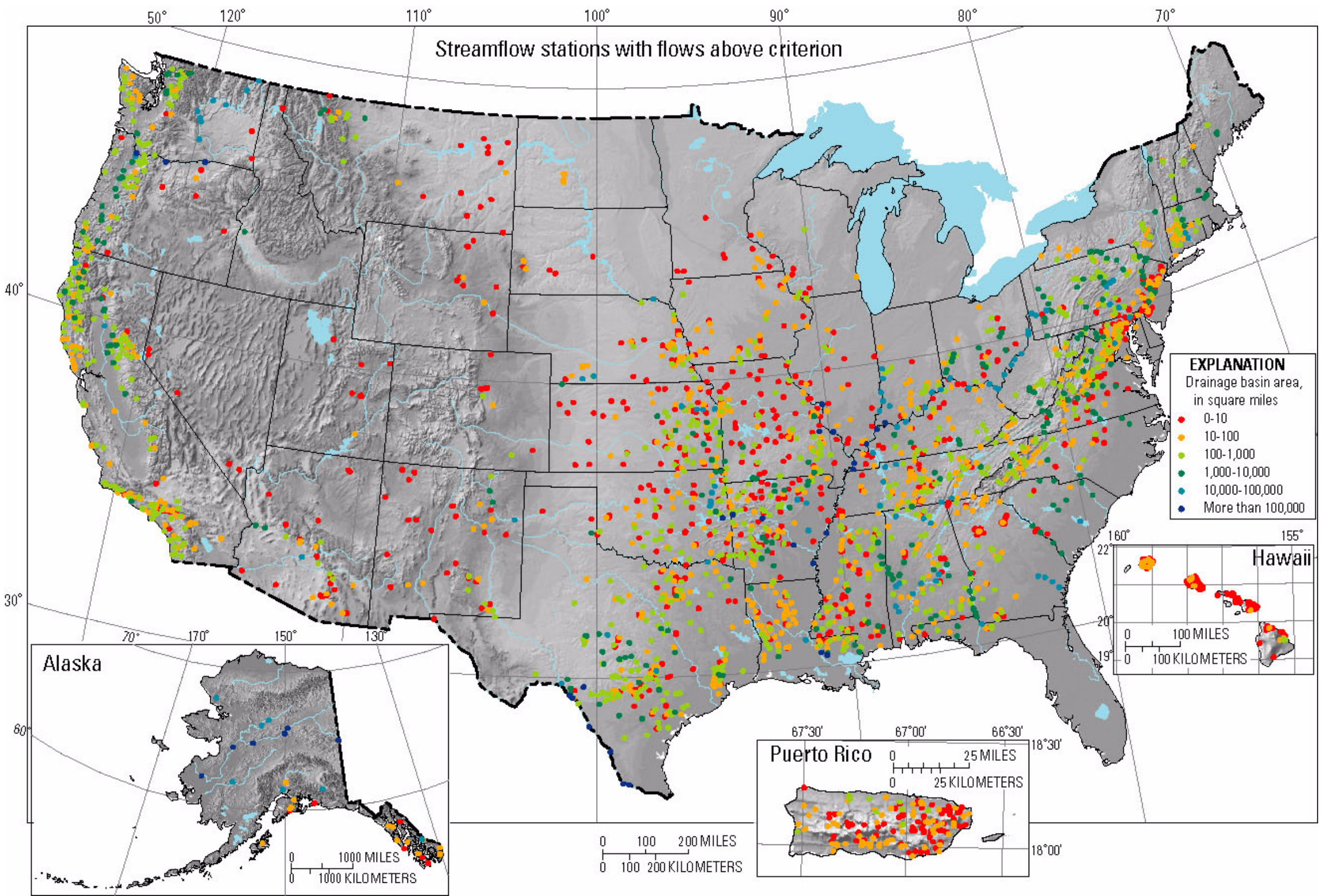

Figure 4. Locations of 2,929 stations, color coded by drainage area, for which the largest peak discharge exceeds the criteria indicated by the red line of figure 3 . The uneven distribution of these stations across the U.S. and Puerto Rico owes to specific climate and landscape characteristics that produce large floods. 


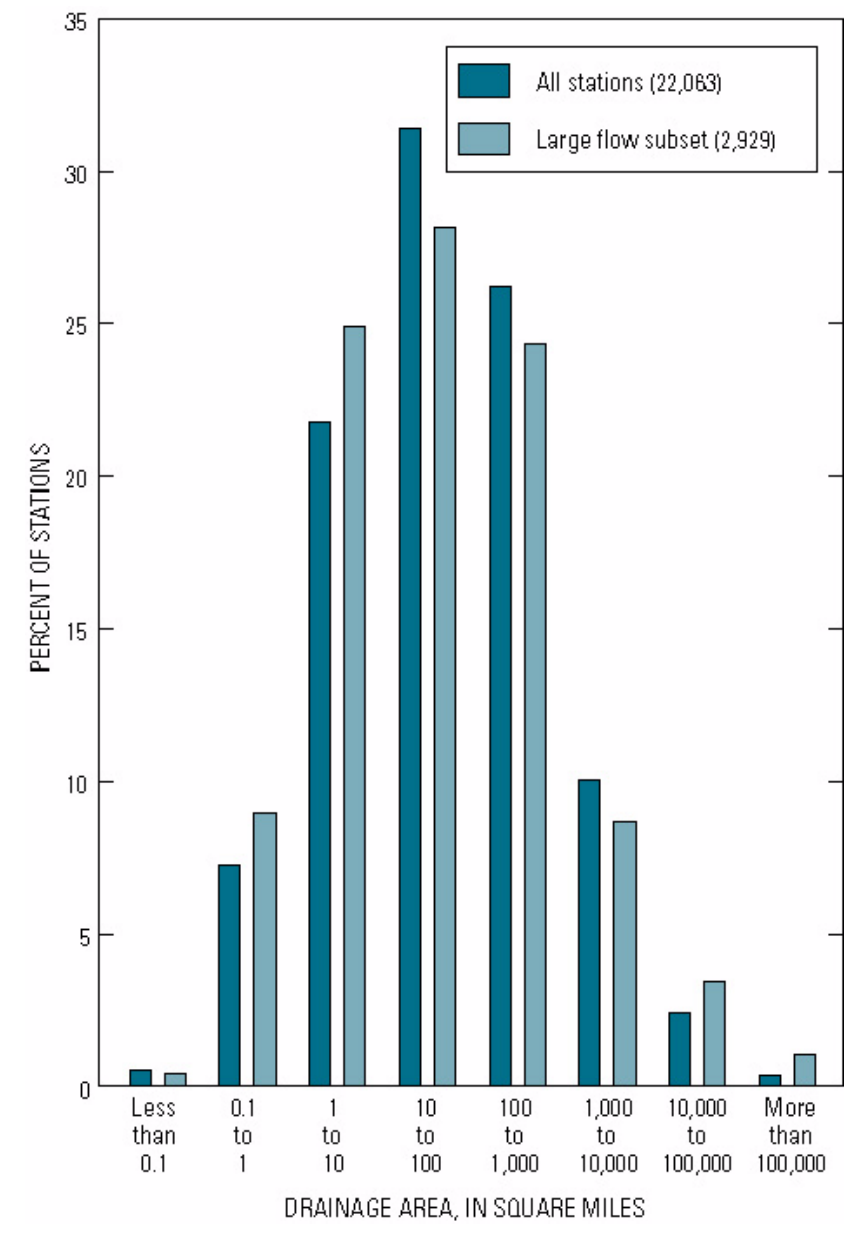

Figure 5. The subset of large-stormflow gaging stations, as defined in this report, has a distribution similar to that of all U.S. Geological Survey gaging stations relative to the size of the basin being gaged.

high flow magnitudes along the Pacific coast. Another area susceptible to relatively large flows is the southern midwestern United States.

Broad areas are also depicted by figure 4 that have very few stations with discharges exceeding the large-flow criteria. In the interior of the western United States, only isolated stations with small drainage basins have had exceptionally large flows. Likewise, very few stations in the northern tier States of the eastern and midwestern parts of the country have had flows exceeding the large-flow criteria. Similarly, very few relatively large flows have been measured in the southeastern coastal plain and Florida.

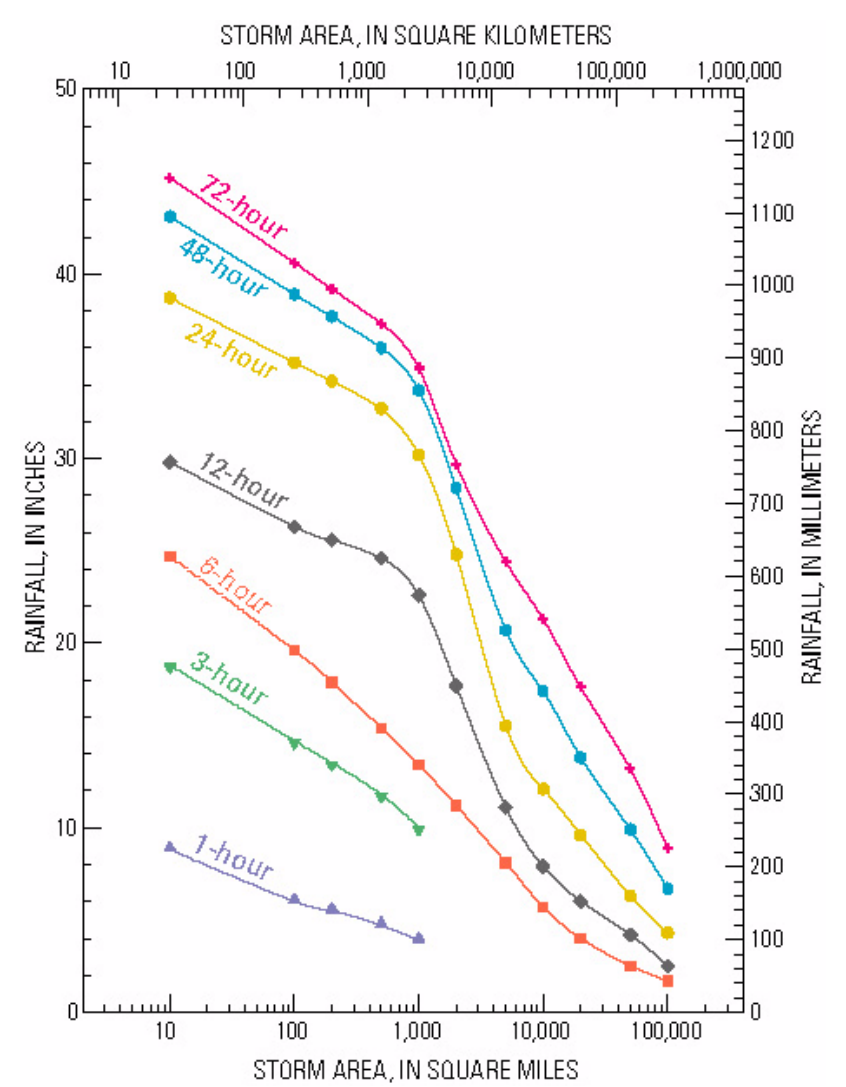

Figure 6. Rainfall amounts are relatively smaller in storms that have a greater than 6 -hour duration and that exceed about 1,000 square miles in area. (Data from World Meteorological Organization.)

\section{WHY ARE LARGE FLOWS WHERE THEY ARE?}

The overall higher density of large-flow stations in the southern States reflects the greater moisture-holding capacity of warmer air. However, most aspects of the distribution of relatively large flows shown in figure 4 are attributable to regional climatic and physiographic conditions. Additionally, basin size influences the nature of climatologic and topographic influences on flow magnitude.

Puerto Rico and Hawaii both have many relatively large flows because they are mountainous areas in the midst of the tradewind belt, where moisture-laden tropical storms and hurricanes are intercepted and forced upward by the island masses, triggering orographic and convective uplift and enhanced precipitation. It follows that a greater proportion of stations with the largest 
flows are on the windward (eastern) side of these island complexes.

Within the eastern conterminous United States, the pattern of large flows closely corresponds to the proximity of subtropical moisture derived from the Gulf of Mexico and the Atlantic Ocean. Finer-scale patterns within this region, however, are clearly linked to topography. Orographic lifting of moisture from the Gulf of Mexico triggers convective instability and has caused concentrations of large floods at topographic features such as the Balcones Escarpment in south central Texas, the Ozark Mountains of western Missouri, and along the eastern edge of the Appalachians on the eastern seaboard. The important role of topographic relief is also illustrated by the lack of exceptional discharges in Florida, and along the coastal plain of the southern and eastern tier States. Despite being closest to the moisture sources and subject to frequent landings of major hurricanes, these relatively flat areas have few stations that have recorded flows exceeding the large-flow criteria of figure 3 .

The high incidence of large flows in the central and southern Midwest and upper Mississippi Valley is partly due to mesoscale convective complexes-large, multiple-celled, persistent thunderstorm systems fed largely by moisture from the Gulf of Mexico (Hayden, 1988; Hirschboeck, 1991). The Rapid City, South Dakota, flood of 1972, the Big Thompson River, Colorado, flood of 1976, and the catastrophic 1993 Mississippi River System flood in the Midwest were caused by such systems.

Within the area of influence of moisture from the Gulf of Mexico, a variety of moisture transport and precipitation processes have caused large

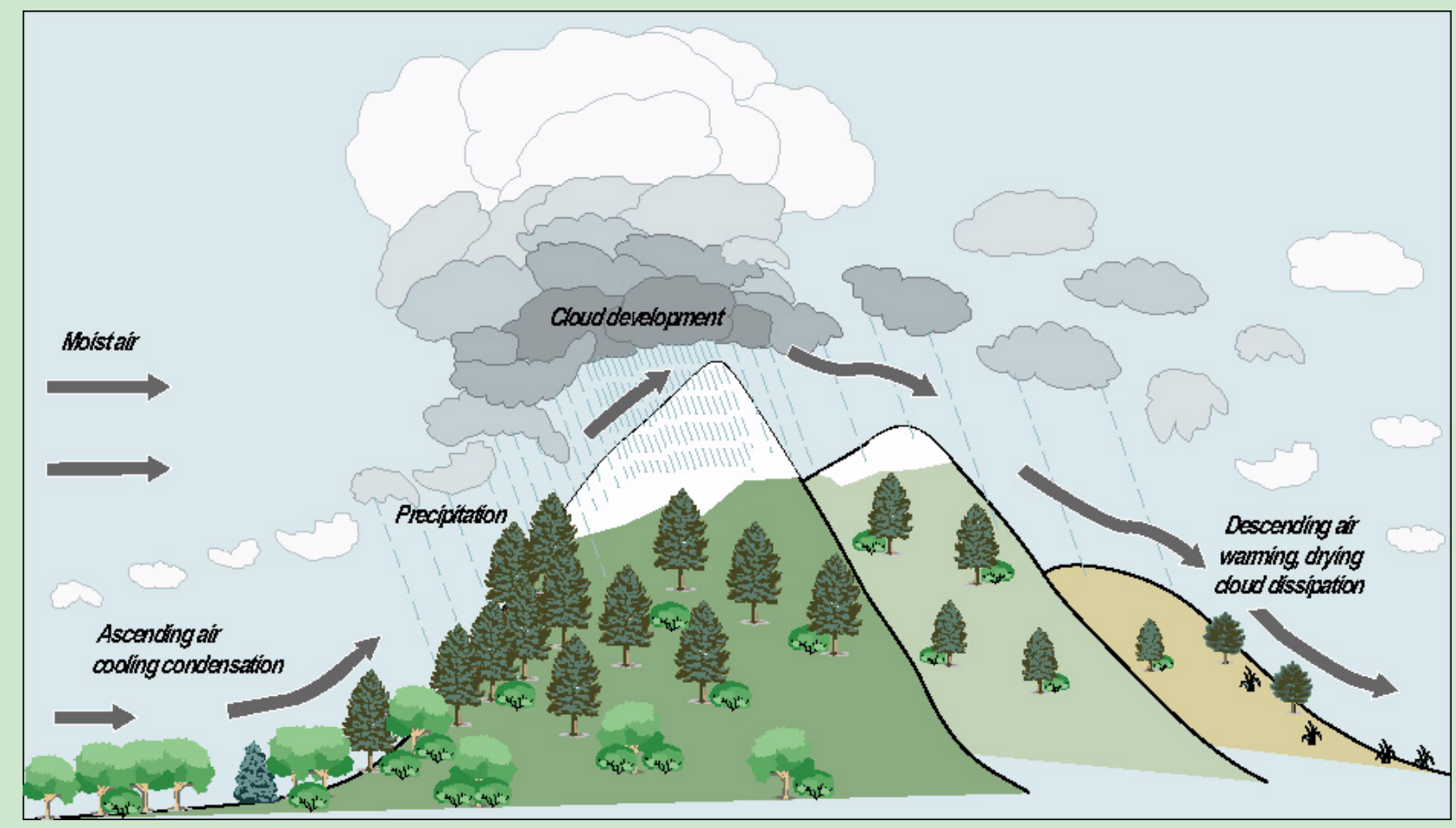

Topography enhances precipitation by:

(a) forcing air to ascend (orographic lifting), causing cooling and, consequently, condensation and precipitation. This is a major factor enhancing rainfall on the western flanks of West Coast mountain ranges.

(b) triggering convective instability either by forcing air masses to rise as they impinge upon upward slopes or by causing differential heating of the ground surface because of the variety of ground surfaces associated with varied topography. In either case, the atmospheric instabilities that result can result in towering cloud growth and intense precipitation. This is a major factor along the flanks of the Appalahians, in the Midwest, and the interior West, wherever mountains and escarpments are in the path of subtropical moisture. 


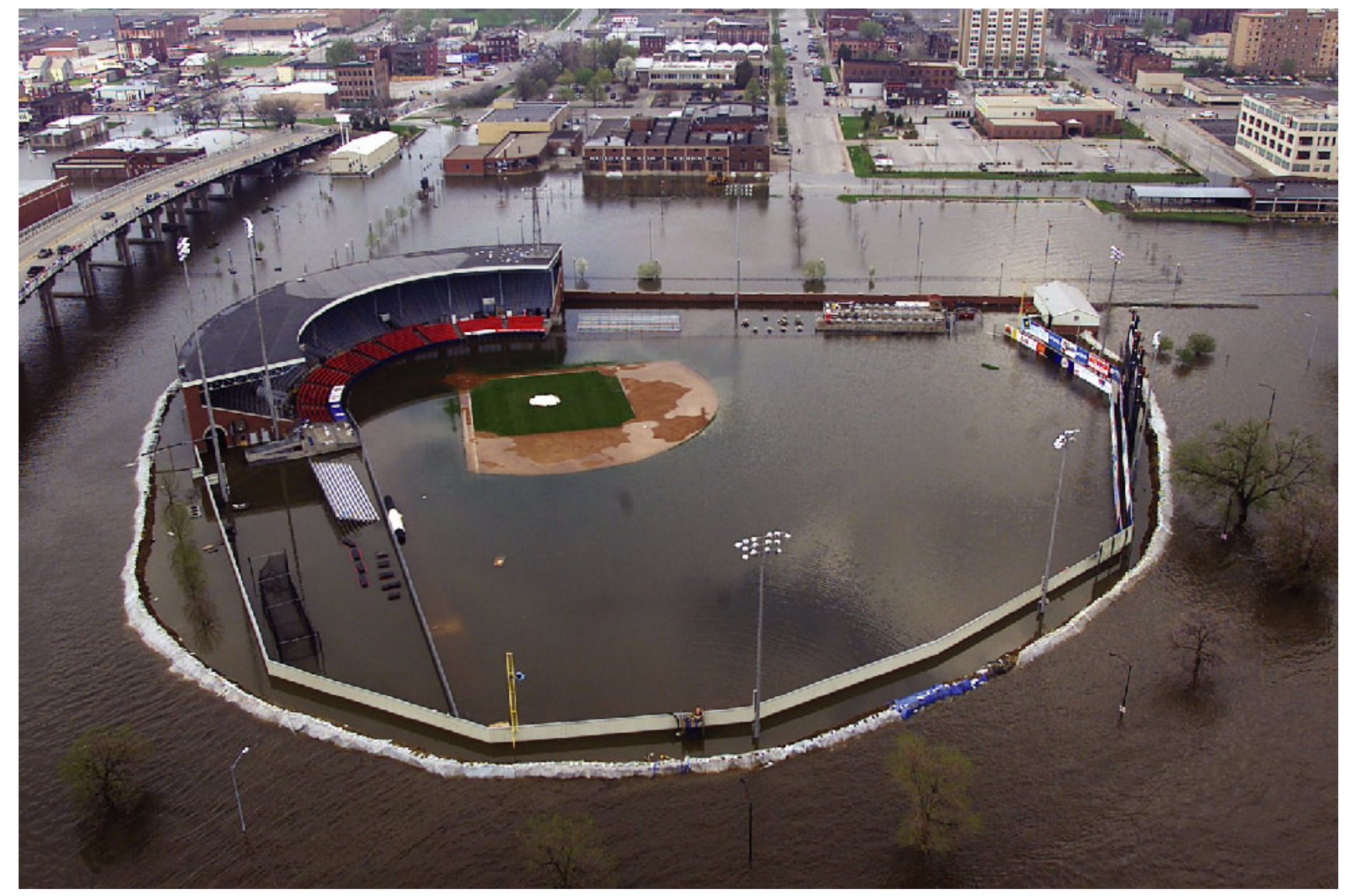

Melting snow and heavy spring rain combined to cause severe flooding on the upper Mississippi River in April 2001. Davenport, lowa, was particularly hard-hit. In this photograph, all but the infield of John O'Donnell Stadium, home of the Quad Cities River Bandits, lies underwater. The record Mississippi River flood of 1993, caused by a persistent mesoscale convective complex, along with other cities in the Mississippi Basin. (Photograph by John Schultz, Quad Cities Times, used by permission.)

flows, including individual thunderstorm cells, mesoscale convective complexes, Atlantic hurricanes, and quasistationary upper atmosphere circulation patterns producing several weeks or months of persistent precipitation. These processes are of such diverse temporal and spatial scales that there does not seem to be any systematic pattern of drainage basin size associated with exceptionally large flows in this region. The only exception is along the southeastern coastal plain, where only larger rivers draining upland areas have produced large flows, primarily from hurricanes.

West of about longitude $105^{\circ}$ west, approximately corresponding to the eastern limit of the Rocky Mountains, moisture from the PacificOcean chiefly influences flooding within the contermi- nous United States and Alaska. Consequently, the stations with largest flows in this region are concentrated along the States contiguous to the Pacific Ocean. The interior western States of Idaho, Nevada, Utah, Wyoming, and Colorado have very few stations with large flows, and, furthermore, the interior West stations that have had relatively large flows generally represent small basins (less than $10 \mathrm{mi}^{2}$ ) influenced by isolated thunderstorms. The distribution of stations with the largest flows within the interior West reflects local orographic lifting and convective instability associated with physiographic features such as the eastern limits of the Rocky Mountains in eastern Wyoming, central Colorado, and eastern New Mexico; the Wasatch Mountains in Utah; and the Mogollon Rim in Arizona. 
Orographic effects are even more pronounced, however, along the western continental margin of North America, where the mountains of southeastern Alaska; Cascade Range of Oregon and Washington; Coast Ranges of Washington, Oregon, and California; and Sierra Nevada and San Gabriel Mountains of California all strongly influence the distribution of stations with large flows. In Oregon, Washington, and northern California, north-south trending mountain ranges intercept the westerly flow of extratropical cyclones from the Pacific Ocean. The largest floods for most basins are winter floods caused by intense cyclonic storms or the combined effects of cyclonic storms and coincident snowmelt. The extensive 1964 and 1996 floods throughout this region were produced by substantial rain-on-snow events. Because these types of storms persist for several days, it is the larger basins-generally from 100 to $100,000 \mathrm{mi}^{2}$ - that are preferentially affected by these types of events (fig. 4).

Large flows in southern California and Arizona are from various sources (Hirschboeck,
1991), including extratropical cyclonic systems, dissipating tropical storms moving northward from the Pacific, mesoscale convective complexes, and local convective thunderstorms. Consequently, there is substantial variation in the size of basins and seasonality of the largest flows. The Transverse Ranges of southern California and Mogollon Rim of central Arizona are oriented in particularly favorable directions to intercept moisture from northward incursions of tropical storms; consequently there are distinct concentrations of stations with large floods aligned along these features.

The big river systems of the Western United States that drain the extensive and snowy mountainous regions of the western North America, such as the Yukon and Columbia Rivers, also produce large flows. These flows are invariably caused by snowmelt in late spring and summer. The large northern basins are the only ones for which snowmelt alone appears to be capable of producing flows greater than the large-flow criterion shown on figure 3 .

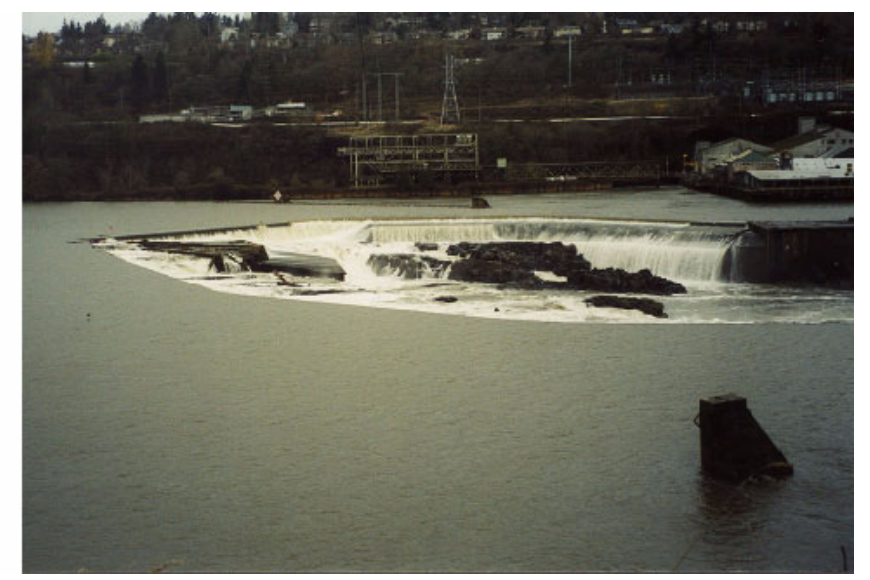

A rain-on-snow flood in February 1996 resulted in near-record to record flooding in the Willamette River Basin and other river basins in Oregon. In the photograph on the left, Willamette Falls (near Oregon City), shown during more typical flow at right, is almost completely submerged. (Photographs by Jim E. O'Connor [left] and John S. Williams [right], U.S. Geological Survey) 


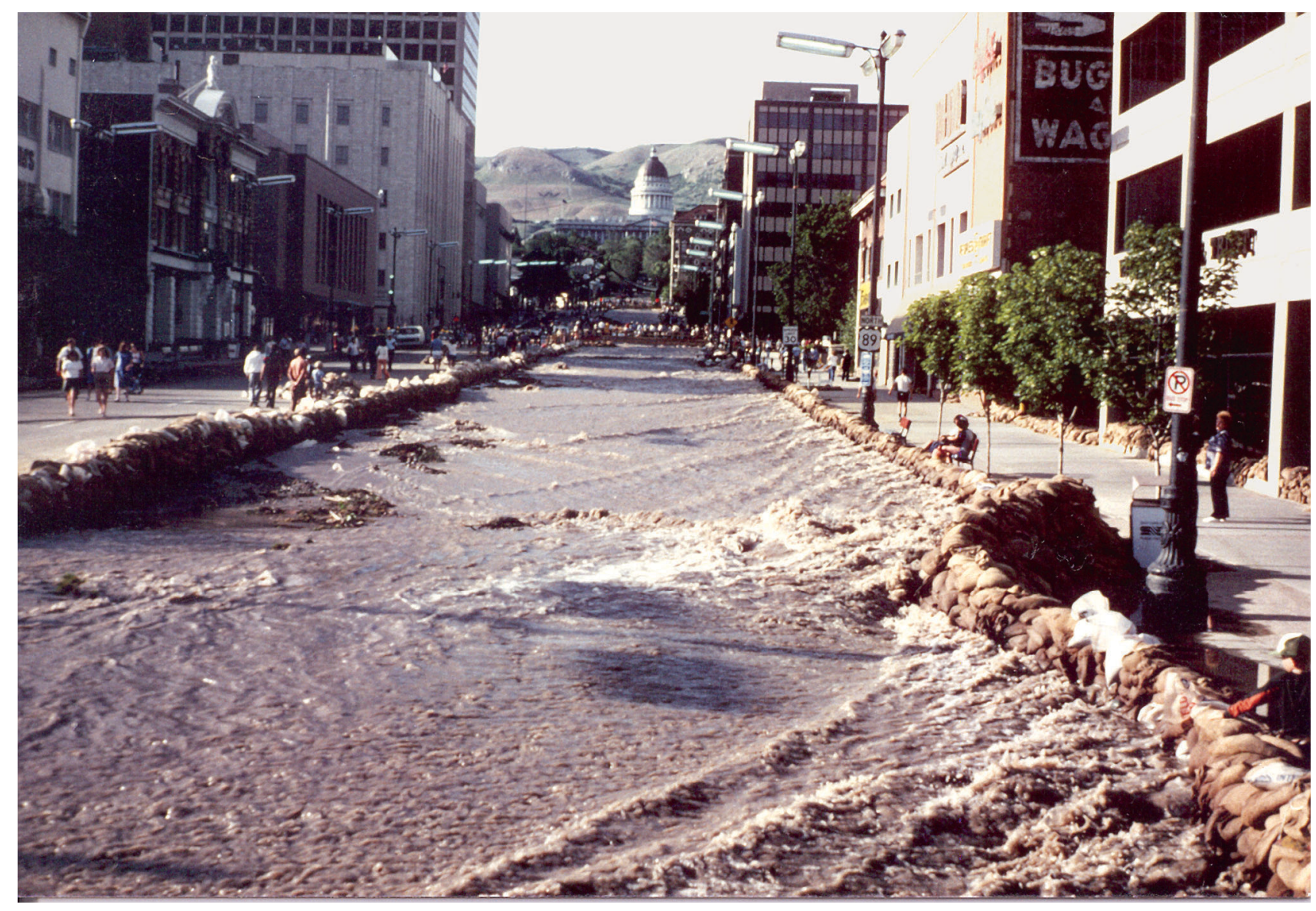

The "State Street River" (floodwater from City Creek) rushes through downtown Salt Lake City, Utah, in May 1983. Rapid melting of a record-water-content snowpack caused the most widespread flooding in the State's history, resulting in damages totaling \$621 million. (Photograph by Rulon Christensen, U.S. Geological Survey.)

\section{SUMMARY}

The spatial distribution of large gaged floods throughout the United States shows that the locations of most of the largest flows are related to specific combinations of regional climatology, topography, and basin size. Key factors include the general northward trend of decreasing atmospheric moisture, proximity to oceanic moisture sources such as the Pacific Ocean and the Gulf of Mexico, and orientation of topographic features relative to directions of moisture flow, with the largest flows being at locations where topographically high areas are oriented perpendicular to directions of moisture flow. Additionally, the largest flows in large river basins are primarily caused by persistent climatologic conditions such as seasonal snowfall. In contrast, the largest flows in smaller basins are most commonly the result of intense precipitation due to convective storms.

Understanding hydrologic extremes, such as floods and droughts, requires records that are both long and of wide spatial extent, especially for a land of such diverse landscapes and climatology as the United States. As one of the few sources of long-term flow measurements, USGS streamflow records are a rich source of data for analyzing the hydrologic conditions of the Nation. As the USGS streamflow measurement program progresses into its second century, it is committed to improving the Nation's level of streamflow information. Components of this commitment include increasing the completeness and efficiency of the streamgaging network, improving methods of data storage and delivery, and new emphasis on analysis of the wealth of information already collected, such as the spatial distribution of large flows described here. 


\section{FOR MORE INFORMATION}

\section{Floods and Climate}

Barry, R.G., and Chorley, R.J., 1998, Atmosphere, weather and climate: London, Routledge, $464 \mathrm{p}$.

Costa, J.E., 1987, A comparison of the largest rainfall-runoff floods in the Unites States with those of the People's Republic of China and the world: Journal of Hydrology, v. 96, p. 101-115.

Hayden, B.P., 1988, Flood climates, in Baker, V.R., Kochel, R.C., and Patton, P.C., eds., Flood Geomorphology: New York, John Wiley and Sons, p. 13-26.

Hirschboeck, K.K., 1991, Climate and floods, in Paulsen, R.W., Chase, E.B,. Roberts, R.S., and Moody, D.W., compilers, National Water Summary 1988-89, Floods and Droughts: U.S. Geological Survey Water-Supply Paper 2375, p. 67-88.

Hoyt, W.G., and Langbein, W.B., 1955, Floods: Princeton University Press, 469 p.

Miller, J.J., 1990, Flood hydrology and geomorphic effectives in the central Appalachians: Earth Surface Processes and Landforms, v. 15, p. 119-134.

Miller, E.W., and Miller, R.M., 2000, Natural disastersFloods-A reference handbook: ABC-CLIO, Santa Barbara, California, 286 p.

O’Connor, J.E., Grant, G.E., and Costa, J.E., 2002, The geology and geography of floods, in House, P.K., Webb, R.H., Baker, V.R., and Levish, D.R., eds., Ancient floods, modern hazards-Principles and application of paleoflood hydrology: American Geophysical Union Water Science and Application Series, no. 5, p. 359-385.

Perry, C.A., 2000, Significant floods in the United States during the 20th century-USGS measures a century of floods: U.S. Geological Survey Fact Sheet 024-00, 4 p.

Pielke, R.A., Jr., and Downton, M.W., 2000, Precipitation and damaging floods-Trends in the United States, 1932-97: Journal of Climate, v. 13, p. 3625-3637.

Schildgen, R.,1999, Unnatural disasters: Sierra, v. 84, p. $48-57$.

\section{The U.S. Geological Survey streamflow measurement program}

Hirsch, R.M., and Norris, J.M., 2001, National Streamflow Information Program-Implementation plan and progress report: U.S. Geological Survey Fact Sheet 048-01, 6 p.
United States Geological Survey, 1999, Streamflow information for the next century-A plan for the National Streamflow Information Program of the U.S. Geological Survey: U.S. Geological Survey Open-File Report 99-456, 13 p.

\section{Related Web sites:}

USGS Water Watch

http://water.usgs.gov/waterwatch/

USGS Fact Sheet: Significant Floods in the United States During the 20th Century

http://ks.water.usgs.gov/Kansas/pubs/fact-sheets/ fs.024-00.html

USGS Flood Information

http://water.usgs.gov/osw/programs/floods.html

EarthSat(TM) flood threat map

http://www.earthsat.com/flood/maps/ffgusa.gif

Federal Emergency Management Agency (FEMA) Flood Hazard Mapping

http://www.fema.gov/mit/tsd/fq_genhm.htm

Dartmouth University Flood Observatory

http://www.dartmouth.edu/artsci/geog/floods/

CBS News Disaster Links

http://www.disasterlinks.net/

Societal Aspects of Weather: Floods

http://sciencepolicy.colorado.edu/socasp/floods.html

National Weather Service: Significant River Flood Outlook http://www.hpc.ncep.noaa.gov/nationalfloodoutlook/ 